\title{
Involvement of the TGFß1/Smad2/MMP3 signaling pathway in SB431542-induced inhibition of cell invasion in multiple myeloma RPMI 8226 cells
}

\author{
HUANG XI $^{1,2}$, QI-GUO SHUAI ${ }^{3}$ and LIN-LI SHAO ${ }^{1}$ \\ ${ }^{1}$ Department of Radiology, College of Basic Medicine, Chongqing Medical University, Chongqing 400016; \\ ${ }^{2}$ Department of Hematology, Hechuan Hospital of The First Affiliated Hospital of Chongqing Medical University, \\ Chongqing 401520; ${ }^{3}$ Department of Radiology, Chongqing Cancer Institute, Chongqing 400016, P.R. China
}

Received February 5, 2016; Accepted January 19, 2017

DOI: $10.3892 / 01.2017 .6263$

\begin{abstract}
Multiple myeloma (MM) is a malignancy characterized by plasma cell hyperplasia. The majority of patients with MM suffer from mortality due to tumor recurrence and metastasis, which has become an emerging clinical problem. Transforming growth factor $\beta 1$ (TGF $\beta 1$ ) has been implicated in tumor metastasis; however, its role in RPMI 8226 cells remains to be elucidated. In the present study, RPMI 8226 cells were treated with various concentrations of SB431542, a TGF $\beta 1$ inhibitor, for 12, 24 and $48 \mathrm{~h}$. RPMI 8226 cells were transfected with lentiviral-TGF $\beta 1$ vectors to overexpress TGF $\beta 1$. Cell proliferation rate was subsequently determined by cell-counting kit- 8 assay and cell invasion was assessed by Transwell assay. Expression of TGF $\beta 1$, SMAD family member 2 (Smad2) and matrix metallopeptidase 3 (MMP3) were analyzed by western blotting. The results demonstrated that cell proliferation and invasion of RPMI 8226 cells was significantly inhibited by SB431542 ( $<<0.05)$. SB431542 was able to significantly downregulate the expression of TGF $\beta 1$, phosphorylated (p)-Smad2 and MMP3; however, the overexpression of TGF $\beta 1$ significantly upregulated the expression of TGF $\beta 1, \mathrm{p}-\mathrm{Smad} 2$ and MMP3. In conclusion, SB431542 reduced cell invasion in RPMI 8226 cells, and this effect may be mediated via the TGF $\beta 1 / \mathrm{Smad} 2 / \mathrm{MMP} 3$ signaling pathway.
\end{abstract}

\section{Introduction}

Multiple myeloma (MM) is a malignancy, which is characterized by plasma cell hyperplasia in the bone marrow and strain integrity of monoclonal immunoglobulin ( $\mathrm{IgG}, \operatorname{Ig} \mathrm{A}, \operatorname{IgD}$ or $\mathrm{IgE}$ ) or Bence Jones protein (free monoclonal light chains $\kappa$ or $\gamma$ )

Correspondence to: Professor Lin-Li Shao, Department of Radiology, College of Basic Medicine, Chongqing Medical University, 1 Medical School Road, Chongqing 400016, P.R. China E-mail: cqykdxls1@163.com

Key words: multiple myeloma, transforming growth factor $\beta 1$, SMAD family member 2, matrix metallopeptidase 3 , cell invasion overexpression (1). Despite active chemotherapy regimes and autologous stem cell transplantation, the majority of MM cases result in mortalities due to tumor recurrence and metastasis, with the incidence and mortality rate on the increase year by year (2). Invasion is a prerequisite of metastasis, which is a leading cause of mortality from tumors and MM $(3,4)$. Therefore, inhibiting cell invasion may benefit patients who have relapsed or have metastatic MM. However, the precise molecular mechanisms of cell invasion in MM remain to be elucidated.

Transforming growth factor $\beta 1$ (TGF $\beta 1$ ) is ubiquitously expressed. TGF $\beta 1$ has been reported to stimulate the production of angiogenic factors and has a critical role in the development and progression of MM (5). In a previous study of aggressive myeloma, cells secreting TGF $\beta 1$ induced tumor epithelial-mesenchymal transition (EMT) and promoted tumor metastasis (6). SMAD family member 2 (Smad2), which mediates TGF $\beta 1$ signaling, has also been reported to be involved in the migration of tumor cells (7).

The role of matrix metalloproteinases (MMPs) in tumor cell metastasis has been well studied, and they been demonstrated to degrade the basement membrane and extracellular matrix (ECM), which is associated with tumor invasion and metastasis (8). MMP3, a member of the family of matrix metalloproteinases, promotes tumor cell invasion and metastasis along the basement membrane via degradation of the ECM (9). It has also been reported that TGF $\beta 1$ stimulates the expression of MMP3 in human corneal epithelial cells (10); however, to the best of our knowledge, this has not been documented in MM cells.

In the present study, the role of SB431542 in the inhibition of cell invasion in multiple myeloma cells and the mechanism of this process were investigated. Furthermore, this present study provided evidence for the involvement of the TGF $\beta 1 / \mathrm{Smad} 2 / \mathrm{MMP} 3$ signaling pathway in the SB431542-induced reduction in cell invasion in multiple myeloma RPMI 8226 cells.

\section{Materials and methods}

Cell culture and reagents. RPMI 8226 cells were purchased from American Type Culture Collection (Manassas, VA, 
USA). Cells were cultured with RPMI 1640 medium with $15 \%$ fetal bovine serum (both Hyclone; GE Healthcare Life Sciences, Logan, USA), in a humidified incubator at $37^{\circ} \mathrm{C}$ with $5 \% \mathrm{CO}_{2}$ for 2 to 3 days. Cells in the logarithmic growth phase were used for subsequent experiments. The primary antibodies anti-glyceraldehyde-3-phosphate dehydrogenase (GAPDH; cat. no. sc-47724; dilution, 1:1,000; Santa Cruz Biotechnology, Inc., Dallas, TX, USA), anti-TGFß1 (cat. no. sc-146; dilution, 1:500; Santa Cruz Biotechnology, Inc.), anti-smad2 (cat. no. 12,052), anti-p-smad2 (cat. no. 11,958) and anti-MMP3 (cat. no. 14351S) (both dilution, 1:1,000) were purchased from Cell Signaling Technology, Inc. (Danvers, MA, USA). The bovine anti-goat IgG horseradish peroxidase-conjugated secondary antibody (cat. no. sc-2352; dilution, 1:1,000) was purchased from Santa Cruz Biotechnology, Inc.

Cell counting kit-8 (CCK-8) cell proliferation assay. RPMI 8226 cells $\left(1 \times 10^{4} / 100 \mu \mathrm{l}\right)$ were seeded in a 96 -well plate for $24 \mathrm{~h}$ and subsequently incubated at $37^{\circ} \mathrm{C}$ in the presence and absence of SB431542 (1.0, 10, 100 and 1,000 nmol/ml; Med Chem Express Co., Monmouth Junction, NJ, USA) for 12, 24 and 48 h. CCK-8 solution (10\%; Dojindo Molecular Technologies, Inc., Kumamoto, Japan) was added, and the plate was incubated at $37^{\circ} \mathrm{C}$ for $3 \mathrm{~h}$. The optical density (OD) of each well was measured at $450 \mathrm{~nm}$ using a microplate reader (Bio-Rad Laboratories, Inc., Hercules, CA, USA). The OD values were calculated based on the formula: Proliferation inhibition rate $=(1-$ mean OD experimental value $/$ mean OD control value)x $100 \%$.

Cell motility assay. Cell invasion was assessed by Transwell assay (pore size, $8 \mu \mathrm{m}$; Corning Inc., Corning, NY, USA). In brief, cells $\left(1 \times 10^{4} /\right.$ well) were treated with SB431542 or lentiviral-TGF $\beta 1$ vectors and the untreated cells $\left(6 \times 10^{4}\right)$ were seeded in the upper chamber. The cells were attached to porous polycarbonate membranes, which were coated with Matrigel basement membrane matrix. The lower chamber was filled with RPMI 1640 medium with $15 \%$ fetal bovine serum. Cells that failed to attach to polycarbonate membranes were removed by washing with PBS following $30 \mathrm{~h}$ incubation at $37^{\circ} \mathrm{C}$, whilst invaded cells were fixed with $4 \%$ paraformaldehyde for $30 \mathrm{~min}$ and subsequently stained with crystal violet dissolved in $1 \%$ SDS for $30 \mathrm{~min}$ at $20^{\circ} \mathrm{C}$. The number of cells in 5 randomly selected visual fields at x200 magnification under a Olympus CX23 light microscope (Olympus Corporation, Tokyo, Japan) was recorded.

Western blot analysis. Cell lysis buffer $[20 \mathrm{mmol} / 1$ Tris (pH 7.5), $150 \mathrm{mmol} / 1 \mathrm{NaCl}, 1 \%$ Triton $\mathrm{X}-100$, protease and phosphate inhibitors $(0.7 \mu \mathrm{g} / \mathrm{ml})$ was added to the cells, which were incubated on ice for $30 \mathrm{~min}$. The cells were subsequently centrifuged at $6,720 \mathrm{x} \mathrm{g}$ at $4^{\circ} \mathrm{C}$ for $12 \mathrm{~min}$, and the supernatants were obtained. The concentration of the total protein was measured using the BCA protein assay (Thermo Fisher Scientific, Inc., Waltham, MA, USA), and protein was heated to $100^{\circ} \mathrm{C}$ with $4 \mu 1$ loading buffer for $8 \mathrm{~min}$. Protein $(40 \mu \mathrm{g})$ was subsequently separated using SDS-PAGE ( $8 \%$ gel) and transferred to polyvinylidene difluoride membranes. The membranes were blocked with $5 \%$ fat-free milk or $5 \%$ bovine serum albumin (Beyotime Institute of Biotechnology, Haimen,
China) for $2 \mathrm{~h}$. The membranes were subsequently incubated with the previously mentioned primary antibodies overnight at $4^{\circ} \mathrm{C}$ and secondary antibodies for $2 \mathrm{~h}$ at room temperature. The blots were visualized using the Millipore-Immobilon ECL kit (EMD Millipore, Billerica, MA, USA) and the blots were quantified with Quantity One software (version 4.62; Bio-Rad Laboratories, Inc., Hercules, CA, USA).

Preparation and transfection of the lentiviral-TGF 1 vector. Double digests of the PLVX-IRES-mcherry plasmid (Laboratory of Neuron Biotechnology Company, Shanghai, China) and vector (GV287), containing the TGF $\beta 1$ gene, with AgeI $(5 \mathrm{U} / \mu \mathrm{l})$ and $E c o R I(20 \mathrm{U} / \mu \mathrm{l})$ (both Beyotime Institute of Biotechnology) were performed. The product was recovered, purified and mixed with $1 \mu 1 \mathrm{~T} 4$ DNA ligase at $16^{\circ} \mathrm{C}$ for $6 \mathrm{~h}$. The transformation of competent DH5 $\alpha$ cells (Takara Bio, Inc., Otsu, Japan) was performed. Briefly, the plasmids $1 \mathrm{ng}$ (5 ul) were cooled in ice for $2 \mathrm{~min}$ and $100 \mu \mathrm{l}$ of competent cells were added to the plasmids. The cells were kept in an ice bath for $5 \mathrm{~min}$ and then plated onto agar plates containing X-Gal, IPTG and ampicillin. White colonies were selected for. Recombinant positive clones were identified by polymerase chain reaction and restriction analysis. The PCR thermocycling conditions used were as follows: Denaturation step, $95^{\circ} \mathrm{C}$ for $5 \mathrm{~min}$; annealing step, $55^{\circ} \mathrm{C}$ for $30 \mathrm{sec}$; elongation step, $72^{\circ} \mathrm{C}$ for $1 \mathrm{~min}$ for 35 cycles; $72^{\circ} \mathrm{C}$ for $10 \mathrm{~min}$; and held at $4^{\circ} \mathrm{C}$. A Taq DNA polymerase kit (Takara Bio, Inc.) was used for PCR. Primer sequences were as follows: TGF $\beta 1$ forward, 5'-ATAAGCTTG ATATCGAATTCCACAGAGCCTTCTCGG-3' and reverse, 5'-GAGGATCCCCGGGTACCGGTCGCCACCATGGCG

CTCTTCGTGCGGC-3'. Plasmids were sent to Biotechnology Co. Ltd. (Shanghai, China) for sequencing. RPMI 8226 cells, in the logarithmic growth phase, were seeded in 6-well plates $\left(2 \times 10^{5}\right.$ cells $\left./ \mathrm{ml}\right)$ and cultured for $24 \mathrm{~h}$. The lentiviral-TGF $\beta 1$ vector was added with a multiplicity of infection value of 80 to RPMI 8226 cells. RPMI 8226 cells were also transfected with GV287 vectors. Non-transfected RPMI 8226 cells served as negative controls. Transfection efficiency was detected by fluorescence microscopy and western blotting at 6 days post-transfection.

Statistical analysis. All experiments were independently performed in triplicate. Student's t-test was performed to compare between two independent sample groups. All statistical analyses were performed using GraphPad Prism software (version 5.01; GraphPad Software, Inc., La Jolla, CA, USA). One-way analysis of variance (ANOVA) was used in conjunction with Fisher's least significant difference post-hoc test to analyze the difference between the concentration groups, and one-way ANOVA with Tukey's test was performed to compare the differences among different treatment groups. $\mathrm{P}<0.05$ was considered to indicate a statistically significant difference.

\section{Results}

SB431542 reduces cell proliferation and invasion in RPMI 8226 cells. To investigate the function of SB 431542 on cell proliferation and invasion, RPMI 8226 cells were treated with 1, 10, 100 and 1,000 nmol/ml SB431542 (Fig. 1A). A significant dose-dependent decrease in cell proliferation was 


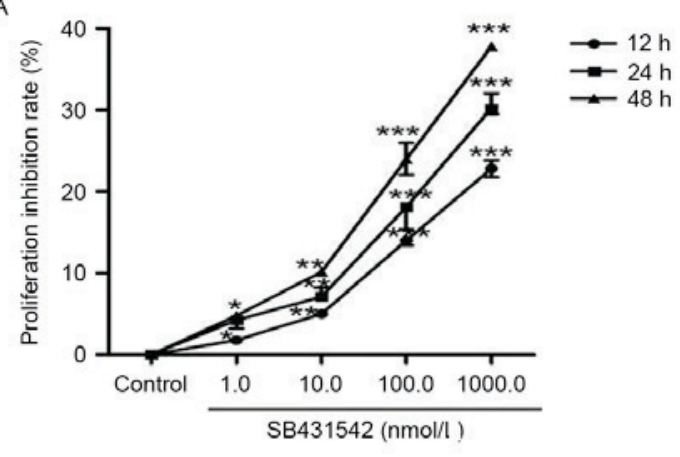

C

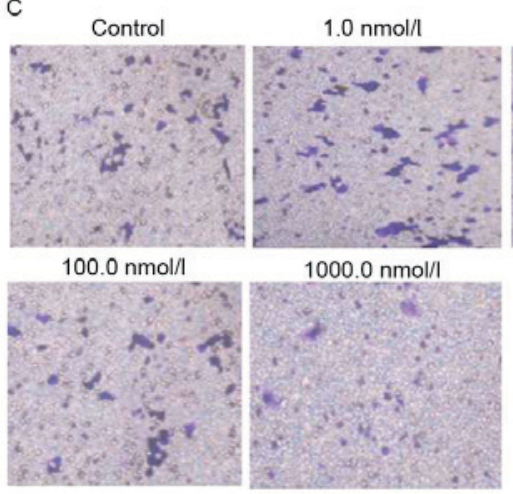

B

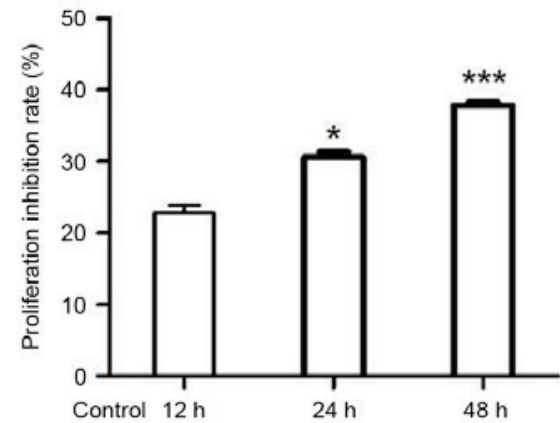

D

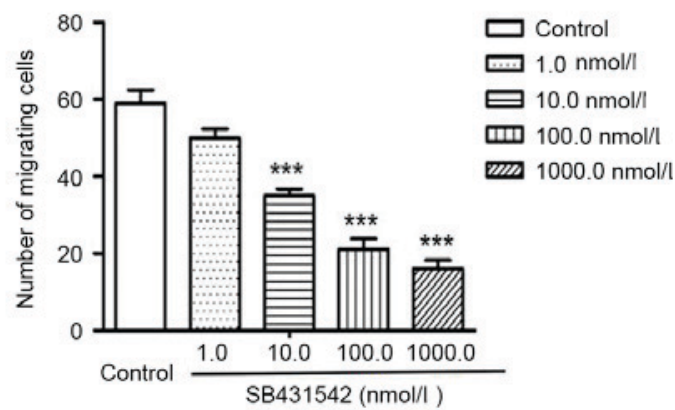

Figure 1. (A) RPMI 8226 cells were treated with SB431542 (1, 10, 100 and 1,000 nmol/l) for 12, 24 and 48 h. The proliferation inhibition rate was measured using a cell-counting kit- 8 assay. (B) The cells were treated with 1,000 nmol/ml SB431542 for 12,24 and $48 \mathrm{~h}$. The proliferation inhibition rate was measured using a cell-counting kit- 8 assay. (C) Cell invasion was measured using a Transwell assay. (D) The number of migrating cells in 10 random fields was counted and the average was calculated. Values are expressed as the mean \pm standard deviation of 3 independent experiments. ${ }^{*} \mathrm{P}<0.05$, ${ }^{* * *} \mathrm{P}<0.01,{ }^{* * *} \mathrm{P}<0.001 \mathrm{vs}$. the control.

A

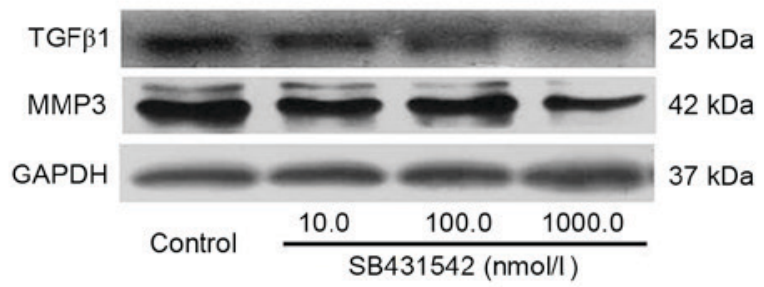

C

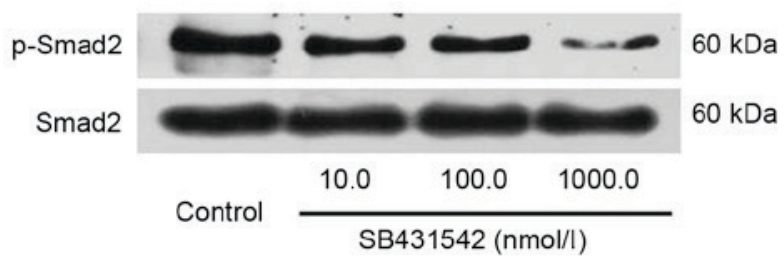

B

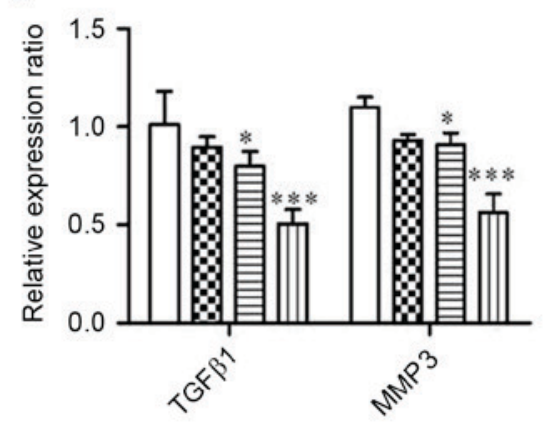

D

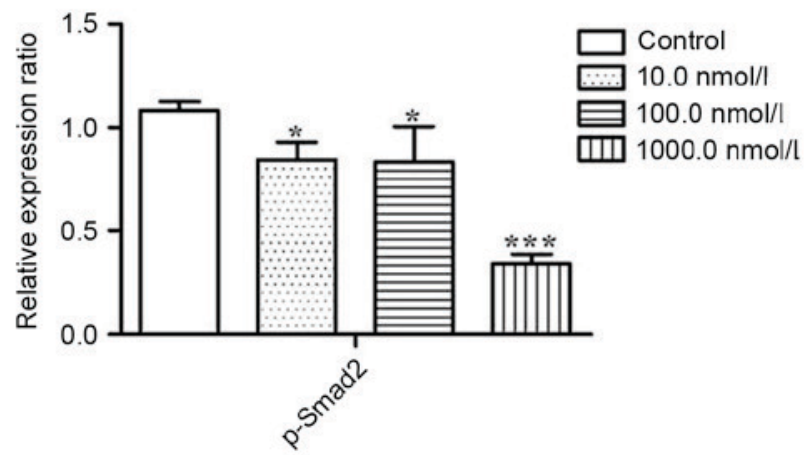

Figure 2. RPMI 8226 cells were treated with SB431542 (10, 100 and 1,000 nmol/l) for $48 \mathrm{~h}$. (A) Representative image and (B) quantification of expression of TGF 31, MMP3 and GAPDH as determined by western blotting. (C) Representative image and (D) quantification of expression of Smad2 and p-Smad2 as determined by western blotting. Values are expressed as the mean \pm standard deviation of 3 independent experiments. ${ }^{*} \mathrm{P}<0.05,{ }^{* * * *} \mathrm{P}<0.001$ vs. the control. GAPDH, glyceraldehyde-3-phosphate dehydrogenase; MMP3, matrix metallopeptidase 3; p, phosphorylated; Smad2, SMAD family member 2; TGF 31 , transforming growth factor $\beta 1$. 
A

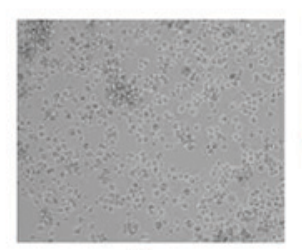
Whitilight

B

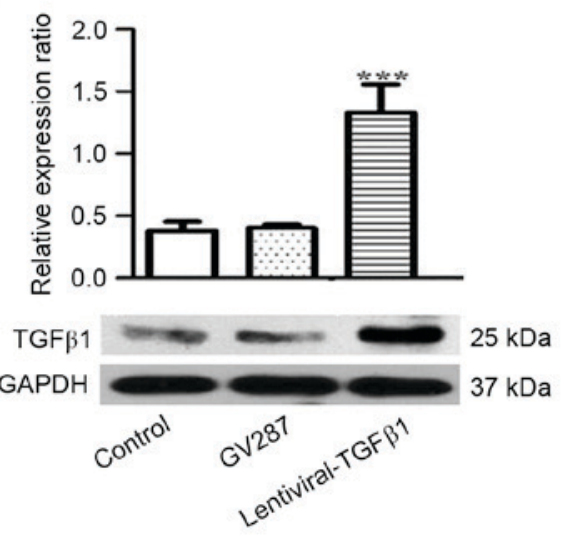

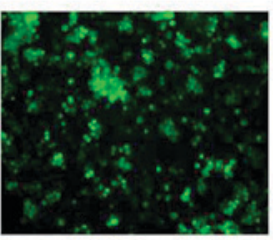
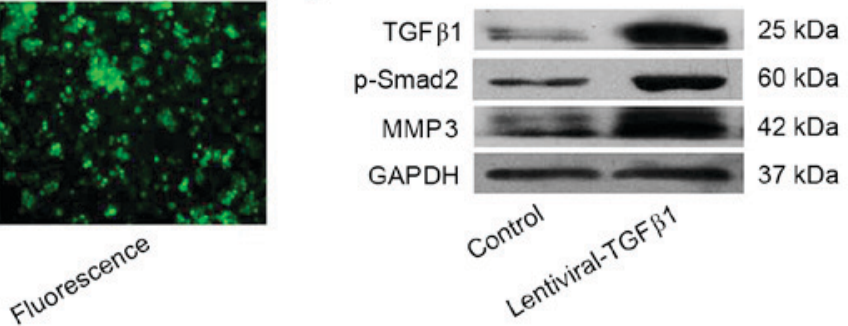

D

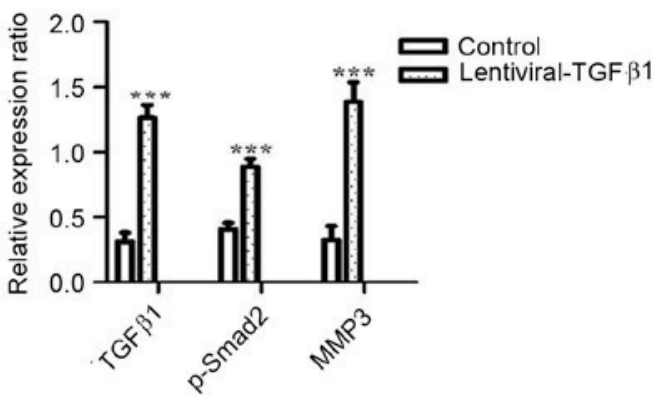

Figure 3. RPMI 8226 cells were transfected with lentiviral-TGF $\beta 1$ vectors and (A) the transfection efficiency was assessed by fluorescence microscopy (B) The expression of TGF 31 was assessed by western blotting in RPMI 8226 cells transfected with lentiviral-TGF 31 vectors, GV287 and non-transfected cells (control). (C) The expression of TGF 31 , p-Smad2 and MMP3 was analyzed by western blotting in RPMI 8226 cells transfected with lentiviral-TGF 31 vectors and in non-transfected cells (control). (D) The ratios of TGF 11 , p-Smad2 and MMP3 relative to GAPDH were calculated. Values are expressed as the mean \pm standard deviation of 3 independent experiments. ${ }^{* * *} \mathrm{P}<0.05$ vs. the control. GAPDH, glyceraldehyde-3-phosphate dehydrogenase; MMP3, matrix metallopeptidase 3; p-Smad2, phosphorylated SMAD family member 2; TGF $\beta 1$, transforming growth factor $\beta 1$.

A

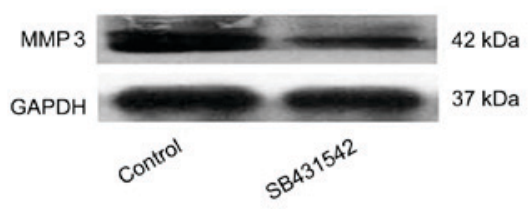

C

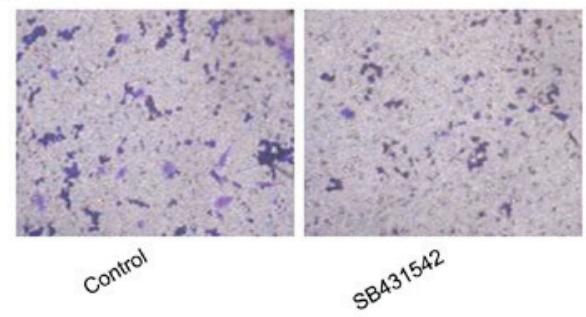

B

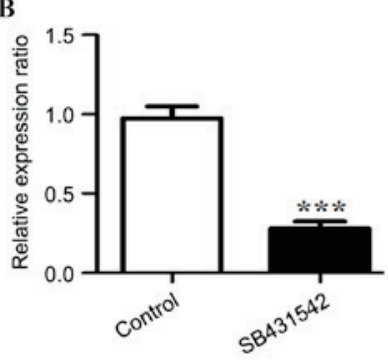

D

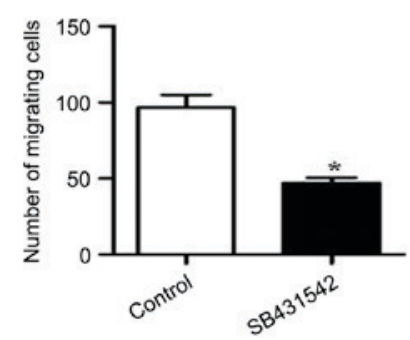

Figure 4. Expression of matrix metallopeptidase 3 in TGF $\beta 1$ overexpressing RPMI 8226 cells treated in the presence and absence of SB431542. (A) Western blotting was performed and (B) ratios relative to GAPDH were calculated. (C) Cell invasion was assessed by Transwell assay and (D) the number of migrating cells was counted. Values are expressed as the mean \pm standard deviation of 3 independent experiments. ${ }^{*}<<0.05,{ }^{* * *} \mathrm{P}<0.001$ vs. the control. GAPDH, glyceraldehyde-3-phosphate dehydrogenase; MMP3, matrix metallopeptidase 3; TGF $\beta 1$, transforming growth factor $\beta 1$.

observed between 1 and 1,000 nmol/1 SB431542. The cells were subsequently treated with $1,000 \mathrm{nmol} / \mathrm{ml} \mathrm{SB} 431542$ for 12, 24 and 48 h (Fig. 1B). Cell proliferation was also inhibited by SB431542 in a dose- and time-dependent manner. Transwell assay was performed to assess cell invasion (Fig. 1C).
The number of migrating cells in the control and SB431542 treatment groups $(1,10,100$ and $1,000 \mathrm{nmol} / \mathrm{ml})$ was $59 \pm 6$, $50 \pm 4,35 \pm 3,21 \pm 5$ and $16 \pm 4$, respectively (Fig. 1D). A significant difference was observed between the control and the 10, 100 and $1,000 \mathrm{nmol} / \mathrm{ml} \mathrm{SB} 431542$ treatment groups $(\mathrm{P}<0.05)$. 
No significant difference was observed between the control and the lowest SB431542 dosage group (1 nmol/ml).

SB431542 reduces TGF $\beta 1$ accumulation, Smad2 activation and MMP3 expression. To investigate the effect of SB431542 on the accumulation of TGF $\beta 1$ and MMP3 in MM cells, RPMI 8226 cells were treated with 10,100 and 1,000 nmol/ml SB431542 for $48 \mathrm{~h}$. Western blotting was performed. The results demonstrated that SB431542 significantly decreased the accumulation of TGF $\beta 1$ and MMP3 at 100 and 1,000 nmol/ml when compared with the control (Fig. 2A and B). Smad2, as a signaling molecule, can be initially activated by TGF $\beta 1$. Therefore, the effect of SB431542 on the expression of Smad2 and phosphorylated (p)-Smad2 in RPMI 8226 cells was investigated. There was no difference in the levels of Smad2 between the different SB431542 treatment groups and the control, but a significant increase in the level of p-Smad2 was demonstrated (Fig. 2C and D), indicating that SB431542 was able to repress the TGF $\beta 1 / \mathrm{Smad} 2$ signaling pathway in RPMI 8226 cells.

Increased expression of $p$-smad2 and MMP3 in RPMI 8226 cells overexpressing TGF $\beta 1$. To investigate the role of TGF $\beta 1$ in the metastasis of MM, RPMI 8226 cells were treated with lentiviral-TGF $\beta 1$ vectors to stably express TGF $\beta 1$. Transfection efficiency was observed under fluorescence microscopy and detected by western blotting (Fig. 3A and B). The expression of TGF $\beta 1$, p-Smad2 and MMP3 was analyzed, and increased expression of $\mathrm{p}$-smad 2 and MMP3 was observed in the cells overexpressing TGF $\beta 1$ compared with the control (Fig. 3C and D).

Cell invasion and MMP3 expression in TGF $\beta 1$ overexpressing RPMI 8226 cells is partly inhibited by SB431542. To investigate the role of SB431542 in RPMI 8226 cells overexpressing TGF $\beta 1$, the expression of MMP3 in the cells treated with SB431542 was analyzed. A significant decrease in MMP3 expression was observed in SB431542 treated group when compare to the control (Fig 4A and B). Cell invasion was assessed by Transwell assay, and a decrease in the number of migrating cells was observed in the SB431542 treated group (Fig. 4C and D).

\section{Discussion}

Human MM is a hematological malignancy, and at present there is limited treatment available (11), with the majority of cases leading to mortality due to metastasis. A requirement of the metastatic process is for cells to acquire invasive capability (12). Therefore, it is a priority to elucidate the mechanism of metastasis in MM. In the present study, the mechanism of metastasis in MM was investigated. It was demonstrated that SB431542 significantly inhibited proliferation and cell invasion in RPMI 8226 cells. Additionally, it was demonstrated that treating RPMI 8226 cells with SB431542 significantly decreased TGF $\beta 1$ expression, Smad 2 phosphorylation and MMP3 expression. Furthermore, overexpression of TGF $\beta 1$ resulted in increased expression of p-Smad2 and MMP3, which could be partly inhibited by SB431542. Taken together, the results demonstrated that SB431542 reduced cell invasion in RPMI 8226 cells via the TGF $\beta 1 / \mathrm{Smad} 2 / \mathrm{MMP} 3$ signaling pathway.

SB431542 is a small molecular inhibitor of TGF $\beta 1$ receptor, and its role in inducing anti-tumor immunity has been previously reported (13). Matsuyama et al (14) demonstrated that SB431542 exerts an anti-tumor effect primarily by inhibiting the proliferation of human osteosarcoma. Likewise, the present study demonstrated that the proliferation of MM cells was inhibited by SB431542 in a dose- and time-dependent manner. A number of studies have reported that TGF $\beta 1$ has growth-stimulating effects on several cell lines, including hepatic stellate cells (15), skin fibroblast (16) and bone marrow-derived mesenchymal stem cells (17). In the present study, TGF $\beta 1$ expression was inhibited by SB431542 in RPMI 8226 cells, leading to an increase in cell proliferation.

The role of TGF $\beta 1$ in promoting tumor metastasis has also been reported in a number of studies (18-20). Likewise, the results of the present study also demonstrated the role of TGF $\beta 1$ in promoting tumor metastasis in RPMI 8226 cells. When the expression of TGF $\beta 1$ was inhibited by SB431542, the number of migrating cells decreased; however, the reverse effect was observed following overexpression of TGF $\beta 1$. The mechanism of TGF $\beta 1$ in regulating cell invasion was also investigated, and this present study demonstrated that MMP3 may be involved and act as a downstream target of TGF $31 /$ Smad 2 signaling.

MMP3 is a member of the MMP family and is a type of proteolytic enzyme involved in the degradation of structural components of the ECM (21), and in the release of precursor forms of growth factors in order to degrade cell-cell and cell-ECM adhesion structure (22). This mechanism contributes to tumor invasion and metastasis. In the present study it was observed that SB431542 was able to significantly decrease MMP3 expression, indicating that SB432542 is able to inhibit cell invasion in RPMI 8226 cells. The role of MMPs in promoting cell invasion and tumor metastasis has been previously reported (23-25), and is associated with EMT. It has also been reported that MMP3 is a target and regulator of EMT $(26,27)$. Furthermore, in the present study, it was demonstrated that overexpression of TGF $\beta 1$ increased MMP3 expression, which may be partly inhibited by SB431542. Therefore, it was concluded that MMP3 expression was regulated by TGF $\beta 1$, and that MMP3 is downstream of TGF $\beta 1 / \mathrm{Smad} 2$ signaling.

In conclusion, overcoming cell invasion and tumor metastasis is a clinical challenge that requires to be addressed and SB431542 may be a potential and valuable drug.

\section{Acknowledgements}

The present study was supported by the Medical research project of the Health Bureau of Chongqing (Chongqing, China; grant no. 2012-2-390).

\section{References}

1. Solomon A, Frangione B and Franklin EC: Bence Jones proteins and light chains of immunoglobulins. Preferential association of the V lambda VI subgroup of human light chains with amyloidosis AL (lambda). J Clin Invest 70: 453-460, 1982. 
2. Kumar SK, Dispenzieri A, Lacy MQ, Gertz MA, Buadi FK, Pandey S, Kapoor P, Dingli D, Hayman SR, Leung N, et al: Continued improvement in survival in multiple myeloma: Changes in early mortality and outcomes in older patients. Leukemia 28: 1122-1128, 2014.

3. Gupta GP and Massagué J: Cancer metastasis: Building a framework. Cell 127: 679-695, 2006.

4. Aggarwal R, Ghobrial IM and Roodman GD: Chemokines in multiple myeloma. Exp Hematol 34: 1289-1295, 2006.

5. Jurczyszyn A, Czepiel J, Biesiada G, Gdula-Argasińska J, Cibor D, Owczarek D, Perucki W and Skotnicki AB: HGF, sIL-6R and TGF- $\beta 1$ play a significant role in the progression of multiple myeloma. J Cancer 5: 518-524, 2014.

6. Toh B, Wang X, Keeble J, Sim WJ, Khoo K, Wong WC, Kato M Prevost-Blondel A, Thiery JP and Abastado JP: Mesenchymal transition and dissemination of cancer cells is driven by myeloid-derived suppressor cells infiltrating the primary tumor. PLoS Biol 9: e1001162, 2011.

7. Ungefroren $\mathrm{H}$, Groth S, Sebens S, Lehnert H, Gieseler F and Fändrich F: Differential roles of Smad2 and Smad3 in the regulation of TGF- $\beta 1$-mediated growth inhibition and cell migration in pancreatic ductal adenocarcinoma cells: Control by Rac1. Mol Cancer 10: 67, 2011

8. Kessenbrock K, Plaks V and Werb Z: Matrix metalloproteinases: Regulators of the tumor microenvironment. Cell 141: 52-67, 2010

9. Deryugina EI and Quigley JP: Matrix metalloproteinases and tumor metastasis. Cancer Metastasis Rev 25: 9-34, 2006.

10. Kim HS, Shang T, Chen Z, Pflugfelder SC and Li DQ: TGF-betal stimulates production of gelatinase (MMP-9), collagenases (MMP-1, -13) and stromelysins (MMP-3, -10,-11) by human corneal epithelial cells. Exp Eye Res 79: 263-274, 2004.

11. Hideshima T, Richardson P, Chauhan D, Palombella VJ, Elliott PJ, Adams J and Anderson KC: The proteasome inhibitor PS-341 inhibits growth, induces apoptosis, and overcomes drug resistance in human multiple myeloma cells. Cancer Res 61: 3071-3076, 2001.

12. Yilmaz M and Christofori G: EMT, the cytoskeleton, and cancer cell invasion. Cancer Metastasis Rev 28: 15-33, 2009.

13. Tanaka H, Shinto O, Yashiro M, Yamazoe S, Iwauchi T, Muguruma K, Kubo N, Ohira M and Hirakawa K: Transforming growth factor $\beta$ signaling inhibitor, SB-431542, induces maturation of dendritic cells and enhances anti-tumor activity. Oncol Rep 24: 1637-1643, 2010.

14. Matsuyama S, Iwadate M, Kondo M, Saitoh M, Hanyu A, Shimizu K, Aburatani H, Mishima HK, Imamura T, Miyazono K and Miyazawa K: SB-431542 and Gleevec inhibit transforming growth factor-beta-induced proliferation of human osteosarcoma cells. Cancer Res 63: 7791-7798, 2003.

15. He Y,Huang C, Sun X,Long XR,Lv XW and Li J: MicroRNA-146a modulates TGF-betal-induced hepatic stellate cell proliferation by targeting SMAD4. Cell Signal 24: 1923-1930, 2012.

16. Liu X, Li P, Liu P, Xiong R, Zhang E, Chen X, Gu D, Zhao Y, Wang Z and Zhou Y: The essential role for c-Ski in mediating TGF-beta1-induced bi-directional effects on skin fibroblast proliferation through a feedback loop. Biochem J 409: 289-297, 2008.
17. Bergfeld SA and DeClerck YA: Bone marrow-derived mesenchymal stem cells and the tumor microenvironment. Cancer Metastasis Rev 29: 249-261, 2010.

18. Sawada T, Kimura K, Nishihara T, Onoda N, Teraoka H, Yamashita Y, Yamada N, Yashiro M, Ohira M and Hirakawa K: TGF-beta1 down-regulates ICAM-1 expression and enhances liver metastasis of pancreatic cancer. Adv Med Sci 51: 60-65, 2006.

19. Biswas S, Guix M, Rinehart C, Dugger TC, Chytil A, Moses HL, Freeman ML and Arteaga CL: Inhibition of TGF- $\beta$ with neutralizing antibodies prevents radiation-induced acceleration of metastatic cancer progression. J Clin Invest 127: 1116, 2017.

20. Bacman D, Merkel S, Croner R, Papadopoulos T, Brueckl W and Dimmler A: TGF-beta receptor 2 downregulation in tumour-associated stroma worsens prognosis and high-grade tumours show more tumour-associated macrophages and lower TGF-beta1 expression in colon carcinoma: A retrospective study. BMC Cancer 7: 156, 2007.

21. Radisky DC, Levy DD, Littlepage LE, Liu H, Nelson CM, Fata JE, Leake D, Godden EL, Albertson DG, Nieto MA, et al: Raclb and reactive oxygen species mediate MMP-3-induced EMT and genomic instability. Nature 436: 123-127, 2005.

22. Egeblad M and Werb Z: New functions for the matrix metalloproteinases in cancer progression. Nat Rev Cancer 2: 161-174, 2002.

23. Casey TM, Eneman J, Crocker A, White J, Tessitore J, Stanley M, Harlow S, Bunn JY, Weaver D, Muss H and Plaut K: Cancer associated fibroblasts stimulated by transforming growth factor betal (TGF-beta 1) increase invasion rate of tumor cells: A population study. Breast Cancer Res Treat 110: 39-49, 2008.

24. Fuxe J, Vincent $T$ and Garcia de Herreros A: Transcriptional crosstalk between TGF- $\beta$ and stem cell pathways in tumor cell invasion: Role of EMT promoting Smad complexes. Cell Cycle 9: 2363-2374, 2010

25. Chen S, Zhu J, Zuo S, Ma J, Zhang J, Chen G, Wang X, Pan Y, Liu Y and Wang P: 1,25(OH)2D3 attenuates TGF- $\beta 1 / \beta 2$-induced increased migration and invasion via inhibiting epithelial-mesenchymal transition in colon cancer cells. Biochem Biophys Res Commun 468: 130-135, 2015.

26. Blavier L, Lazaryev A, Shi XH, Dorey FJ, Shackleford GM and DeClerck YA: Stromelysin-1 (MMP-3) is a target and a regulator of Wnt1-induced epithelial-mesenchymal transition (EMT). Cancer Biol Ther 10: 198-208, 2010.

27. Robichaud N, del Rincon SV, Huor B, Alain T, Petruccelli LA, Hearnden J, Goncalves C, Grotegut S, Spruck CH, Furic L, et al: Phosphorylation of eIF4E promotes EMT and metastasis via translational control of SNAIL and MMP-3. Oncogene 34: 2032-2042, 2015 . 